
\title{
3 Research Soure \\ Determinants of Financial Management Practice: The Case of Micro and Small Enterprises in East Gojjam Zone, Ethiopia
}

\section{Gedefaw Asres ( $\nabla$ gedefaw86@gmail.com )}

Debre Markos University College of Business and Economics https://orcid.org/0000-0002-5486-2250

\section{Beza Muche Teka}

Debre Markos University College of Business and Economics

\section{Research}

Keywords: Determinants, financial management practice, micro and small enterprises, East Gojjam Zone

Posted Date: December 3rd, 2020

DOI: https://doi.org/10.21203/rs.3.rs-117192/v1

License: (9) (1) This work is licensed under a Creative Commons Attribution 4.0 International License. Read Full License 


\section{Abstract}

Purpose

Financial management is defined as the overall arrangement for planning, directing, monitoring, organizing, and controlling of the economic resources of an organization, with a view to efficient accomplishment of the enterprise objectives. It is well recognized that financial management practice has a key reason for the success of those enterprises and it is the main issue for any business type. However, the status of effective financial management practice in developing countries especially in Ethiopia is at its infant stage. Thus, the main objective of the study is to investigate the determinants of financial management practice of micro and small enterprises in East Gojjam Zone.

Method

The type of research applied in this study is explanatory/causal/ in nature. Questionnaires were used to collect primary data. The combination of purposive stratified and systematic sampling techniques were applied to select respondents. A multiple linear regression model was used to test the casual relationship between the study variables.

Findings

The findings indicated that financial management knowledge, financial management attitude, size of enterprise, locus of control, and use of information technology have positive and significant effect on financial management practice. However, gender, owner's age, and enterprise age have no statistically significant effect on financial management practice of micro and small enterprises.

Suggestion

The study suggested that financial management experts should provide financial management training for micro and small enterprise owners/managers.

\section{Introduction}

Financial management practice is a global issue that increases the profitability of any business type and it is the key instrument for success of any Business. Sound financial management practice has a great contribution for micro and small enterprises all over the world. It improves the performance of any business. Financial management knowledge becomes an increasingly valuable skill for any decision making practice in the $21^{\text {st }}$ century economy. Financial management is important for any institutional success whereas ineffective financial management, combined with other factors in an organization can often lead to severe problems (Lakew \& Rao, 2012). Micro and small businesses are the driving force for the growth and development of the economies of many countries in the world including Ethiopia. It is also noted in various literatures that such contribution of the small scale enterprises to the economy become realistic only with effective financial management practice (Derbie \& Kassahun, 2013). Lack of adequate financial management skill of owners / managers is one of the major reason behind poor financial management practice of micro and small business enterprises (Jindrichovska, 2013). Regardless of their level of development, micro and small business enterprises has significant contribution towards the economic development of all countries around the world (Abanis et al., 2013). In the world, small, medium and 
micro enterprises play a great role in absorbing labor, penetrating new markets and generally enhancing an enabling environment for entrepreneurship. This is partly due to the fact that small, medium and micro enterprises tend to be more labor-intensive and therefore have a higher labor-absorption capacity than big businesses (Jacqui \& Macquet, 2002). For instance, in the United States of America, small businesses introduce innovative products and services, created jobs, opened foreign markets and in the process sparked the US economy. In Japan, small businesses account for the bulk of the country's established businesses that provide sustainable jobs. In Taiwan, micro and small businesses enterprises account for $98 \%$ of the gross domestic product (Landzani, 2004). In Africa, in order to improve the economic conditions and poverty issue, small businesses can play a greater role as the driving force of economic growth and poverty reduction (Okpara, 2011). Any strategy for poverty alleviation in Africa must include support, encouragement and promotion of MSEs. For example, in South Africa, $90 \%$ of new job employment were created by small, medium and micro-business enterprises between 1985 and 2005 (Cohen, 2012). In Ethiopia, micro and small enterprise sector has a great importance particularly for the low-income, poor and women groups which is evident from their relatively large presence, share in employment and small capital requirement. These are sufficient reason for governments and other stakeholders in development to be interested in micro and small enterprises. Micro and small business enterprises are considered as the major means of providing employment, alleviating poverty, ensuring food security, and private sector development around the globe. However, in the context of many developing countries and countries in transition, particular in Ethiopia, MSEs are also seen as an emerging private sector, forming the basis for private-sector-led growth (Gebrehiwot \& Wolday, 2001). More specifically as per Amhara region, East Gojjam Zone, Ethiopia, MSEs office report (2019), Micro and Small enterprises have a great significance economic contribution by creating a job opportunity and creation of wealth for more than 47,482 owners without including employees and other participants in five sectors including manufacturing, construction, service, trade and urban agriculture. Therefore, this indicates that Micro and Small businesses have significance contribution for the development of the economy and hence they have to exercise better financial management practice by identifying key determinants. The contribution of MSE for economic development is highly depending on the success of MSE. To make micro and small business enterprises more successful, a manager should acquire a wide range of small business management skills including more importantly financial management skill (Urban \& Naidoo, 2012). However, Prior studies on the management of small and medium industries advocate that even management functions such as planning, organizing, staffing, directing, and controlling are not done properly in many of such industries. That is why many small and medium industries financial management practice is very poor. Lack of adequate financial management knowledge skill and experience of managers, failure in selection of the staff on the basis of their micro and small business management skill, non-dedication of responsibilities to members, insufficient commitment of managers and lack of access to information, failure in proper processing of information, and so on are the major reasons for these barriers (Asil \& Naralan, 2016). MSEs are also poorly managed due to the lack of management skills among owners or managers. They lack awareness of the importance of adopting business best practices and quality management systems, such as financial management and customer focused activities, in order to increase the firms' productivity and profitability. As a result of the above mentioned problems, MSEs are unable to compete effectively in the market (Radam, Abu and Abdullah, 2008). Further, many micro and small enterprise owners fail because they are unable to understand basic financial concepts or practices. Even in developed countries, entrepreneurs have not sufficient financial management skill, an issue which is obvious in the small business and enterprise world. It's widely recognized that throughout the globe, micro and small businesses have a high rate of failure. In the U.S Small Business Administration had noted that fifty percent (50\%) of small businesses fail in the first year and ninety-five percent (95\%) fail within the first five years (European Federation of Accountants, 2004). A research conducted by Harif et al. (2010) with regard to the financial management practices of MSEs in Malaysia 
indicated that lack of working capital which accounted for 93.6 per cent is the most common weakness in the area of financial management practice. The issue of financial management in developing countries is not so much satisfactory. Especially in Ethiopia, financial management practice is at very severe level. This is because most business enterprises have not appointed financial managers to be in charge of financial management of the enterprise. Usually, the owners or general managers act as the assistance of the accountant control financial matters of the enterprise. On the other hand, most owners/managers have no formal training in management skills, especially financial management. In addition, the concepts of financial management have also only been recognized in Ethiopia since the beginning of the 1960s, when the commercial code was introduced by the then imperial government. Hence, financial management is still one of the challenges of business enterprises in Ethiopia (Deresse and Rao, 2012). Additionally, in Ethiopia, the owners of small businesses have no adequate financial management skills and training, most small businesses do not engage in financial planning, analysis, and control; do not set short and long term financial objectives; do not analyze the trend in sales, cost and profit (Solomon, 2017). Further, lack of awareness and knowledge, lack of follow up and inability to maintain qualified accountants are also the major factors that hinder to adopt best financial management practice. Therefore, the main objective of the study was to investigate determinants of financial management practice of micro and small enterprises in East Gojjam Zone, Ethiopia.

\section{Literature Review}

\section{Determinants of Financial Management Practice and Hypothesis Formulation}

\subsection{Financial Management Knowledge}

Financial management knowledge is the capability to use relevant knowledge and understanding to planning, organizing, directing and controlling or managing the financial activities of an enterprise or efficient utilization of resources (Lusardi and Mitchell, 2007). Eagly\&Chaiken (1993) indicated that financial knowledge is a factor that has an impact on financial management practice. Further, Thi et al. (2015) in his research indicated that financial knowledge has a significant positive effect on financial management behavior because financial knowledge based education will increase insight about financial management behavior. Therefore, in this study, it was hypothesized that:

H1: Financial management knowledge has significant effect on financial management practice.

\subsection{Financial Management Attitude}

Financial management attitude is defined as a state of mind, opinion and judgment of a person about financial management (Jodi \& Phyllis, 1998) . Further, as per Parrotta and Johnson (1998), financial attitude can be considered as the psychological tendency expressed when evaluating recommended financial management practices with some degree of agreement or disagreement. Financial attitudes influence the way people spend, save and waste money (Furnham, 1984). On the same case, Godwin (1994) when tested the impact of financial attitudes on financial management by setting attitudes as an independent variable, found that a positive attitude toward planning was the greatest predictor of cash flow management. Joo and Grable (2004) find that, people with stronger perceptions and positive financial attitudes tend to more successful in financial management practice. Contrarily, Rejina et al. (2011) states that financial attitude has a significant negative effect on financial management which implies that a person with good financial management attitude may have bad financial 
management practice. Thus, in this study, based on findings from majority of past studies, it was hypothesized that:

\section{H2: Financial attitude has significant effect on financial management practice.}

\subsection{Locus of Control}

According to Hellrigel et al. (2010) locus of control is defined as the extent to which individuals believe that they can control events which affect them. Thiet al. (2015) on his study indicated that locus of control has a significant negative effect on financial management behavior. By contrast, Listiani (2017) found that the better locus of control a person has, the better becomes pattern of financial management behavior and it implies that locus of control has significant positive effect on financial management behavior. Therefore, in this study, it was hypothesized that:

\section{H3: Locus of control has significant effect on financial management practice}

\subsection{Use of Information Technology}

Use of Information Technology is defined as usage of tools and machines to solve real world problems (Gupta, 2008). It refers to a variety of computerized technologies that enables communication and the electronic transmission of information (Ashrafi and Murtaza, 2008). These technologies include desktop computers, laptops, hand-held devices, wired or wireless connectivity, business productivity software, data storage \& security, network security, other related protocols, etc. ICT has the ability to enhance the effective utilization of financial management practices. According to Bharadwaj (2000) the use of technology at firm level reckoned to have positive impact on firm practices. According to Berisha (2009), the use of information technology by MSEs can benefit them by developing competences for managing, reduce the transaction costs and develop capability to gather information. Buhimila and Dong (2018) asserted that there is a significant relationship between the use of technology and firm financial management practices. Adoption and actual use of more sophisticated information technology in developing countries would have a cunningly better way of MSEs sound financial management practices and performance (McChlery et al., 2005). In addition, the inability of small firms to make use of computerized accounting systems also act as a barrier to the successful implementation of sound financial management practices(Agyei-Mensah, 2011). Therefore, in this study, it was hypothesized that:

\section{H4: Usage information technology has significant effect on financial management practice}

\subsection{Size of Enterprise}

According to Pandey (2012) enterprise size can be expressed in a number of ways such as amount of capital invested, number of employees, the technology used in the operation and its market coverage or size of enterprise refers to employees per establishment, employees per company, sales per firm and value added per firm or total assets of the enterprise (SBA, 2014). The size of MSE affects the competitiveness of the firm as well as the operation of the enterprise. The larger the enterprise size, they acquire better resources, economies of scale, able to have advanced equipment's, knowledgeable employees, and others. In the opposite, the smaller the Enterprise size, limited access to capital, low number of employees, has no that much advanced technology and so on. Rathnasiri (2015) study determined that there is statistically significant differences between the category of small and medium scale enterprises in adopting accounting, cash management practices and fixed asset management practices. Everaert et al. (2006) indicated that the need to prepare a complete set of financial statements increases 
as an entity progresses from small to medium size. It is at the medium-size stage that financial performance reporting will be useful to internal and external users. Therefore, the hypothesis is formulated as:

\section{H5: Enterprise size has significant effect on financial management practice}

\subsection{Age of Enterprise}

Age of enterprise is defined as the number of years of the establishment of the business. Wambui, Kimani, \& Muhavani (n.d) on their study indicated that institutional age and effectiveness of financial management practice are positively and significantly associated but Rathnasiri (2015) concluded that the number of years that business has been in operation under existing management is not a significant variable for varying adoption of financial management. Thus, the hypothesis is formulated as:

\section{H6: Enterprise age has significant effect on financial management practice.}

\subsection{Age of the Owner}

Age of owners refers to the number of years the owner have starting from born. Elizabeth et al. (1998) in their study indicated that owner's age has significant positive effect on financial management practice. They indicated that the older the participant, the better becomes financial management practices adopted. By contrast, Asandimitra and Kautsar(2017) indicated in their study that age has negative significant impact on the success of MSEs management by women entrepreneurs which implies that the younger women entrepreneurs, the more success in managing the MSEs. Thus, the hypothesis is formulated as:

\section{H7: Owner's age has significant effect on financial management practice}

\subsection{Gender}

Gender is defined as range of characteristics given to human beings as male and female. A study done by Fatimah et al. (2013) indicated that there is significant relationship between gender and financial management practices. The result implies that males are better financial managers than the female practitioners. On the other hand Hira et al. (1992) and parrota \& Johnson (1998) found that no relationship between gender and financial management. This means that gender has no influence on financial management practice of SMEs. Thus, based on the findings from majority of previous works, in this study it was hypothesized that:

\section{H8: Gender has significant effect on financial management practice.}

\section{Conceptual Framework}

A conceptual framework is a research tool intended to assist a researcher to develop awareness and understanding of the situation under review. It shows the interaction of dependent and independent variables. The independent variables are those factors (Financial management knowledge, financial attitude, locus of control, Enterprise size, Enterprise age, use of information technology (computer), owner's age and gender whereas the dependent variable is financial management practice.

\section{Research Methodology}

\subsection{Research Design}


The research design used in this study was explanatory because explanatory research aims at establishing the cause and effect relationship between variables.

\subsection{Total Population}

The total populations of Micro and Small Enterprises of East Gojjam Zone in 20 woredas (Aneded, Awabel, BasoLiben, Bibugni, DebayTelat, Debre Elias, DebreMarkos, Dejen, EnarjEnawga, EnbsieSarMidir, Enemay, Goncha, sede, Gozzamn, HuletEjiEnesie, Machakel, ShebelBerenta, Sinan, Bichena and Motta) are 47,482 in the year 2019. There are 27,989 micro and small enterprises in the selected six weredas (DebreMarkos, Sinan, Motta, Bichena, Gozzamn, and Debre Elias) in the year 2019. The total population from each selected woredas with respect to their business sectors is presented as follows:

\section{Table 1: Total Population from Each WoredaBy Sector}

\begin{tabular}{|c|c|c|c|c|c|c|c|c|c|c|c|}
\hline \multirow[t]{3}{*}{ Woreda } & \multicolumn{11}{|c|}{ Sectors } \\
\hline & \multicolumn{2}{|c|}{ Manufacturing } & \multicolumn{2}{|c|}{ Construction } & \multicolumn{2}{|c|}{ Service } & \multicolumn{2}{|l|}{ Trade } & \multicolumn{2}{|c|}{ Urban Ag. } & \multirow[t]{2}{*}{ Total } \\
\hline & Micro & Small & Micro & Small & Micro & Small & Micro & Small & Micro & Small & \\
\hline D/Markos & 833 & 95 & 1977 & 82 & 1287 & 283 & 1978 & 19 & 502 & 30 & 7086 \\
\hline Sinan & 169 & 1 & 279 & 0 & 580 & 12 & 917 & 24 & 1005 & 0 & 2987 \\
\hline Gozzamn & 192 & 5 & 665 & 0 & 583 & 35 & 549 & 18 & 4210 & 17 & 6274 \\
\hline Motta & 390 & 60 & 954 & 42 & 674 & 52 & 2085 & 65 & 116 & 38 & 4476 \\
\hline D/Elias & 220 & 15 & 410 & 30 & 334 & 37 & 580 & 69 & 2567 & 0 & 4262 \\
\hline Bichena & 330 & 11 & 382 & 2 & 499 & 34 & 1529 & 38 & 79 & 0 & 2904 \\
\hline Total & 2134 & 187 & 4667 & 156 & 3957 & 453 & 7638 & 233 & 8479 & 85 & 27989 \\
\hline
\end{tabular}

\section{Source: East Gojjam Zone micro and small enterprise office report, 2019}

\subsection{Sampling Technique}

The study was used a combination of stratified sampling method (stratification based on type of business they were engaged i.e. manufacturing, construction, service, trade and urban agriculture), systematic sampling technique (used to select respondents from each stratum's) and purposive (to select six woredas from 20 woredas of East Gojjam Zone). The selected six woredas include: DebreMarkos, Sinan, Motta, Bichena, Gozzamn, and Debre Elias. This woredas were selected because of the existence of large number of MSEs as compared to others in the Zone.

\subsection{Sample Size Determination}

The researcher found sample size (n) from the total population at 95\% confidence level by using Yemane (1967) sample size determination formula. 


$$
\mathrm{n}=\quad \underset{1+\mathrm{N}}{\underline{\mathrm{N}}(\mathrm{e})^{2} \quad \text { Where, } \mathrm{N}=\text { Population size, e= sampling error }}
$$

Therefore, $\mathrm{n}=\underline{27,989} \quad=\underline{27,989}=394.36$ approximately 394

$$
1+27,989(.05)^{2} \quad 70.97
$$

To calculate and determine the sample from each stratum, the researchers were used proportional allocation i.e. sample size in stratum one is equal to total sample size divided by the total population and multiplied by the total population of the specific stratum (Crawford, 1990). Therefore, the researcher was determined a sample size from each stratum as follows:

$\mathrm{P}=$ sample size $=\underline{394}=0.014$ where, $\mathrm{p}=$ proportion

\begin{tabular}{|c|c|c|c|c|c|c|c|c|c|c|c|}
\hline \multirow[b]{3}{*}{ Woreda } & \multicolumn{11}{|c|}{ Sectors } \\
\hline & \multicolumn{2}{|c|}{ Manufacturing } & \multicolumn{2}{|c|}{ Construction } & \multicolumn{2}{|c|}{ Service } & \multicolumn{2}{|l|}{ Trade } & \multicolumn{2}{|c|}{ Urban Ag. } & \multirow[t]{2}{*}{ Total } \\
\hline & Micro & Small & Micro & Small & Micro & Small & Micro & Small & Micro & Small & \\
\hline D/Markos & 11 & 1 & 27 & 1 & 18 & 4 & 27 & 1 & 7 & 1 & 98 \\
\hline Sinan & 2 & 1 & 4 & 0 & 8 & 1 & 12 & 1 & 14 & 0 & 43 \\
\hline Gozzamn & 2 & 1 & 9 & 0 & 8 & 1 & 7 & 1 & 58 & 1 & 88 \\
\hline Motta & 5 & 1 & 13 & 1 & 9 & 1 & 29 & 1 & 2 & 1 & 63 \\
\hline D/Elias & 3 & 1 & 5 & 1 & 4 & 1 & 8 & 1 & 36 & 0 & 62 \\
\hline Bichena & 5 & 1 & 5 & 1 & 6 & 1 & 21 & 1 & 1 & 0 & 40 \\
\hline Total & 28 & 6 & 63 & 4 & 53 & 9 & 104 & 6 & 118 & 3 & 394 \\
\hline
\end{tabular}

Total population $\quad 27,989$

Table 2: Actual Sample Size of Each Woreda by Sector

Note: From the above table, $n=N^{\star} p$ where, $N=$ Total population from each strata and $p=$ proportion i.e. $n / N$.

Source: Own calculation, 2019

\subsection{Source of Data and Method of Data Collection}

The study was used only primary sources of data and the primary data was collected through open and close ended questionnaires from micro and small enterprise owners/managers of East Gojjam Zone. The items in the questionnaire were mainly adopted from previous empirical studies with some modifications (Addo, 2017; Marris, 2005 and Rejna et al., 2011). In order to improve its reliability, the questionnaire was converted from English version to Amharic version and then distributed those questionnaires to respondents.

\subsection{Method of Data Analysis}


After data was collected from primary data sources through close and open ended questionnaires, in order to examine the effect of explanatory variables on financial management practice, the data have been analyzed by using multiple linear Regressions analysis and STATA version 13 was used as a data analysis tool. This is because multiple regression analysis is useful in determining whether or not a particular effect is present, in measuring the magnitude of a particular effect and in forecasting what would be of a particular effect (McCartney et. al., 2006). To analyze Likert scale questionnaires, first of all, it is necessary to calculate a composite score (sum or mean) from four or more Likert items and then the study used parametric statistic such as mean for central tendency, standard deviation for variance and regression (Boone and Boone, 2012).

\subsection{Model Specification}

The study was used multiple linear regression model (OLS) and the estimated regression equation for this study is formulated using the equation below:

$\mathrm{FMP}=\beta_{0}+\beta_{1} \mathrm{FMK}+\beta_{2} \mathrm{FMA}+\beta_{3} \mathrm{LC}+\beta_{4} \mathrm{UIT}+\beta_{5} \mathrm{ES}+\beta_{6} \mathrm{GEN}+\beta_{7} \mathrm{OAGE}+\beta_{8} \mathrm{EAGE}+\varepsilon$

Where, $\mathrm{FMP}=$ Financial management practice, $\mathrm{FMK}=$ Financial management Knowledge, FMA= Financial Management Attitude, LC=Locus of control, UIT=Use of Information Technology, ES= Enterprise size, GEN= Gender, OAGE $=$ Owners Age, EAGE = Enterprise age, $\beta_{0}=$ constant term, $\boldsymbol{\varepsilon}=$ error term and $\beta_{1}, \beta_{2}, \beta_{3}, \beta_{4}, \beta_{5}, \beta_{6}, \beta_{7}$ and $\beta_{8}$ are beta coefficients of FMK, FMA, LC, UIT, ES, GEN, OAGE and EAGE respectively.

\subsection{Definition and Measurement of Variables Included in the Model}

Financial management practice refers to the systems of efficient and effective management of resources in such a manner as to accomplish the objectives of the organization (Chung \& Chuang, 2010). Financial management practice is measured using Likert scale (1-not practiced to 5- very highly practiced) and then to convert it in to continuous variable, mean value of all likert scale items were calculated.

Financial management knowledge is the capability to use relevant knowledge and understanding to planning, organizing, directing and controlling or managing the financial activities of an enterprise like efficient utilization of resources (Lusardi and Mitchell, 2007). Financial management knowledge is measured using Likert scale (1strongly disagree to 5- strongly agree).

Financial management Attitude is defined as a state of mind, opinion and judgment of a person about financial management (Jodi \& Phyllis, 1998) and measured by using Likert scale (1-strongly disagree to 5- strongly agree).

Locus of Control is defined as the extent to which individuals believe that they can control events which affect them (Hellrigel et al, 2010) and measured using Likert scale (1-strongly disagree to 5- strongly agree).

Use of Information Technology is defined as usage of tools and machines to solve real world problems (Gupta, 2008) measured using Likert scale (1-strongly disagree to 5- strongly agree)

Size of Enterprise refers to employees per establishment, employees per company, sales per firm and value added per firm or total assets of the enterprise (SBA, 2014) and measured by Logarithm of total assets.

Gender is defined as range of characteristics given to human beings as male and female (dummy variable or Nominal scale 0 for male and 1 for female) 
Age of Enterprise refers to the number of years of the establishment of the business enterprise measured in number of years in operation (continuous variable).

Age of owners refers to the number of years the owner have starting from born and measured by Nominal scale (1 for 18 to 30 years, 2 for 31 to 45 years, 3 for 46 to 65 years and 4 for above 65 years).

\section{Data Analysis And Discussion}

\subsection{Diagnostic Tests}

The primary assumptions reviewed in this study include normality, homoscedasticity, multicollinearity, and model specification test. When assumptions are violated accuracy and inferences from the analysis are affected (Antonakis\& Dietz, 2011). Accordingly, the study was tested the following assumptions:

\subsubsection{Normality Test}

The assumption of normality can be tested in different ways such as histogram, kdensity (kernel density estimate), normal p-plot, Q-plot, skewness and kurtosis. But, PP-plots are more exacting methods to spot deviations from normality, and are relatively easy to interpret as departures from a straight line (Keith, 2006). Therefore; the researcher was checked normality of residuals by normal PP-plots and as indicated from figure 2 , the data is normally distributed.

\subsubsection{Multicollinearity Test}

The data must not show multicollinearity, which occurs when there exist two or more independent variables that are highly correlated with each other. The researcher was checked this assumption in STATA through an inspection of correlation coefficients or Tolerance/variance inflation factor (VIF) values. As a rule of thumb, multicollinearity problem exists if the VIF of a variable exceeds or equal to 10 (Hair et al., 2010).

Table 3: Multicollinearity Test

\begin{tabular}{|lll|}
\hline Variable & VIF & 1/VIF \\
\hline FMK & 1.54 & 0.649676 \\
\hline FMA & 1.76 & 0.566991 \\
LC & 1.64 & 0.611536 \\
UIT & 1.16 & 0.860714 \\
\hline ES & 1.08 & 0.925708 \\
\hline GEN & 1.03 & 0.973416 \\
\hline OAGE & 1.12 & 0.895875 \\
\hline EAGE & 1.10 & 0.912754 \\
\hline Mean VIF & 1.30 & \\
\hline
\end{tabular}

Source: STATAoutput, 2020 
Therefore, as indicated from the value of variance inflation factor (VIF), there is no multicollinearity problem.

\subsubsection{Heteroscedasticity Test}

The assumption of homoscedasticity refers to equal variance of errors across all levels of the independent variables (Osborne \& Waters, 2002). However, it is good to note that the regression is fairly robust to violation of this assumption (Keith, 2006). Therefore, in order to solve this problem the researcher was applied robust regression.

\subsubsection{Model Specification Test (Omitted Variable Test)}

The STATA output indicated that there is no omitted variable (model specification error) since Ramsey test indicates p-value of 0.2389 which is above 0.05 . Therefore, the model is specified correctly.

Table 4: Model Specification Test Using Omitted Variable Test

\begin{tabular}{|l|}
\hline Ovtest \\
\hline Ramsey RESET test using powers of the fitted values FMP \\
\hline Ho: model has no omitted variables \\
\hline$F(3,344)=1.41$ \\
\hline Prob $>F=0.2389$ \\
\hline
\end{tabular}

Source: STATA output, 2020

\subsection{Model Summary}

Table 5: Model Summary

\begin{tabular}{|c|c|c|c|}
\hline \multicolumn{4}{|c|}{ reg FMP FMK FMA LC UIT ES GEN OAGE EAGE, robust } \\
\hline \multicolumn{4}{|c|}{ Number of observations $=356$} \\
\hline & & $F(8,347)$ & $=63.72$ \\
\hline \multirow[t]{3}{*}{ Prob $>F$} & $=0.000$ & & \\
\hline & & R-Squared & $=0.6052$ \\
\hline & & Root MSE & $=.5161$ \\
\hline
\end{tabular}

Source: STATA result, 2020

The goodness fit of the model is tested using R square. The value of R-square statistics of the model was $60.52 \%$. This value indicated that $60.52 \%$ of variation in the dependent variable (FMP) is described by the independent (explanatory) variables and the other $39.48 \%$ was explained by other factors which are not involved in this model. Moreover, $\mathrm{F}$ value of 0.000 indicates that it is significant supporting the model pertinent to the study.

\subsection{Regression Result}




\begin{tabular}{|lllllll|}
\hline FMP & Coefficient & $\begin{array}{l}\text { Robust } \\
\text { Std. Err. }\end{array}$ & $\mathbf{t}$ & $\mathrm{P}>|\mathrm{t}|$ & \multicolumn{2}{l}{ [95\% Conf. Interval] } \\
\hline FMK & .4468479 & .0510542 & 8.75 & $0.000 *$ & .3464332 & .5472626 \\
\hline FMA & .2477823 & .0407805 & 6.08 & $0.000 *$ & .1675743 & .3279903 \\
\hline LC & .10182 & .0399098 & 2.55 & $0.011 * \star$ & .0233245 & .1803154 \\
\hline UIT & .0810066 & .038755 & 2.09 & $0.037 * \star$ & .0047823 & .1572309 \\
\hline ES & .1713805 & .0516077 & 3.32 & $0.001 *$ & .0698812 & .2728798 \\
\hline GEN & -.0320187 & .0552877 & -0.58 & 0.563 & -.1407599 & .0767224 \\
\hline OAGE & -.0325568 & .031134 & -1.05 & 0.296 & -.093792 & .0286783 \\
\hline EAGE & .0088084 & .0110144 & 0.80 & 0.424 & -.012855 & .0304718 \\
\hline Cons & -.6115809 & .2346091 & -2.61 & 0.010 & -1.073016 & -.1501462 \\
\hline
\end{tabular}

\section{Source: STATAoutput, 2020 ( $*=$ significant at $1 \%$ and **=significant at $5 \%$ level of confidence)}

\subsection{Discussion of Findings}

\subsubsection{Financial Management Knowledge}

Financial management knowledge has a positive and statistically significant influence on financial management practice with a positive coefficient of .4468479 and significant at $1 \%$ level of significant ( $p$-value=0.000). The result indicates that an increase (decrease) in financial management knowledge of owners/managers results an increase (decrease) in the financial management practice of micro and small enterprises. This implies that lack of financial management knowledge combined with uncertainty of the business environment often leads MSEs to face serious problems regarding financial and overall performances, which can even threaten the survival of the enterprise (Alpkan \& Kaya, 2012). This result is consistent with Thiet al. (2015) which indicated that financial knowledge has positive and significant effect on financial management practice because the role of education with related to financial knowledge will increase insight about financial management practice and an increase in financial knowledge would lead an increase in performance of financial management practice. In addition, Joo (2009, as cited in Nyaga, 2016) stated that effective financial management skills should improve financial well-being in a positive way and failure to manage finances well can lead to long term negative social consequences.

\subsubsection{Financial Management Attitude}

Financial management attitude has a positive and statistically significant influence on financial management practice with a positive coefficient of .2477823 and significant at $1 \%$ level of significance ( $p$-value $=0.000)$. The result indicates that an increase (decrease) in financial management attitude of owners/managers results an increase (decrease) in the financial management practice of micro and small enterprises. Meaning that the more individuals able to apply a good financial attitude, it also has a good effect on the management of business finance. That means a more positive in financial attitude; the more becomes their financial management practice. This is due to the quality of the financial attitude derived from the quality of good education of a person and able 
to apply in everyday life (Listianis, 2017, as cited in Prihartono and Asandimitra, 2018). The finding implies that people with stronger perceptions and positive financial attitudes becomes more successful in their financial management practice (Joo and Grable, 2004). Therefore, individuals express different beliefs about financial management but according to this study and other previous researcher's owners/managers having strong financial attitude leads to good financial management practice. This fact is supported by furnham (1984) who stated that financial attitude shape the way people spend, save, and waste money.

\subsubsection{Locus of Control}

Locus of control has a positive and statistically significant influence on financial management practice with a positive coefficient of .10182 and significant at $5 \%$ level of significance ( $p$-value=0.011). The result indicates that an increase (decrease) in locus of control results an increase (decrease) in the financial management practice of micro and small enterprises. This result is in line with Listiani (2017) which stated that the better locus of control a person have, the better becomes their pattern of financial management behavior or in other words his finding implies that locus of control has a significant positive effect on financial management behavior. By contrast, this result is not in line with Thi et al (2015) which indicated that locus of control has a significant negative effect on financial management behavior or someone with good locus of control tends not to apply good financial management practice.

\subsubsection{Use of Information Technology}

Use of information technology has a positive and statistically significant influence on financial management practice with a positive coefficient of .0810066 and significant at $5 \%$ level of ( $p$-value $=0.037$ ). The result indicates that an increase (decrease) in use of information technology results an increase (decrease) in the financial management practice of micro and small enterprises. This implies that the better micro and small enterprises will use information technologies; the better becomes effective their financial management practice. This result is consistent with Buhimila and Dong (2018) and Agyei-Mensah (2011) which stated that the availability of affordable computers and suitable software has played an important role in promoting the practice of sound financial management. In addition, McChlery et al. (2005) also identified that the use of computerized accounting system as a major factor in promoting sound financial management.

\subsubsection{Enterprise Size}

Size of enterprise is used as a factor of financial management practice and measured by the logarithms of total assets. Size of enterprise has a positive and statistically significant influence on financial management practice with a positive coefficient of .1713805 and at $1 \%$ level of significance ( $p$-value=0.001). The result indicated that an increase (decrease) in size of enterprises in the aspect of assets results an increase (decrease) in the financial management practice of micro and small enterprises. The result is in line with previous empirical studies which revealed that the need to financial management practice increases as an entity progresses from small to medium size which implies that enterprise size has positive influence on financial management practice (Everaert et al., 2006 and Rathnasiri, 2015).

\section{Conclusion And Recommendation}

The regression result indicted that financial management knowledge, financial management attitude and size of enterprise have statistically significant influence on financial management practice at $1 \%$ level of significance ( $p$ -

Page $13 / 20$ 
value $=0.001$ ). On the other hand, locus of control and use of information technology have statistically significant influence on financial management practice at $5 \%$ significance level since the $p$ values for the two variables were 0.011 and 0.037 respectively. However, gender, owner's age, and enterprise age were not statistically significant effect on financial management practice ( $p$-value $=0.563,0.296$ and 0.424 respectively). Based on the above result the researcher recommends that financial management training is important to improve financial management knowledge and hence financial management practice of owners/managers. Therefore, the government should continuously provide financial management training for micro and small enterprise owners/managers. In addition, using information technology is very important for effective financial management practice. Information technologies (computers) are used to easily record transactions; to prepare, analysis and report financial statement to users, and store relevant information for long period of time. Therefore, owners/managers of micro and small enterprises should use information technologies to improve their financial management practice. Reading makes human beings good viewers for things and knowledge can be improved through reading. Therefore, owners/manager of micro and small enterprises should improve their financial management knowledge by reading different financial management texts or by acquiring formal/informal educations from different educational institutions.

\section{Limitations and Directions for Future Researchers}

The limitation of this study is the usage of only primary data. Therefore, future researchers should considered this limitation and it is better to conduct a research on the same title by adding new variables like level of education, experience of the owners/managers, rules and regulations and also by including secondary data. It is also advisable to conduct a research on the same title in households, banks, universities and other public organizations in Ethiopia.

\section{Abbreviations}

ES: Enterprise Size; EAGE: Enterprise Age; EGZ: East Gojjam Zone; FMP: Financial management Practice; FMK: Financial Management Knowledge; FMA: Financial Management Attitude; GAAP: Generally Accepted Accounting Principles; GEN: Gender; GDP: Gross Domestic Products; ICT: Information Communication Technology; IFRS: International Financial Reporting Standard; LC: Locus of control; MSEs: Micro and Small Enterprises; OAGE: Owner Age; OLS: Ordinary Least Square; UIT: Use of information Technology; MSEs: Micro and Small Enterprises.

\section{Declarations}

Acknowledgment: Not applicable

Authors Contribution: Both authors have contribution to the study and preparation of the final manuscript.

Authors Information: This research manuscript is done by Mr. Gedefaw Asres and Dr. Beza Muche Teka. Mr. Gedefaw Asres and Dr. Beza Muche Teka are currently working as a lecturer and assistant professor as well as researcher (respectively) in Debre Markos University, Ethiopia, College of Business and Economics, Department of Accounting and Finance. Dr. Beza Muche has six publications in reputable international journals.

Funding: This research is done by the researchers' themselves and no funding opportunity from any source. 
Availability of Data and Materials: The datasets used and/or analyzed during the current study will be available from the corresponding author on reasonable request.

Competing Interest: The authors declare that they have no competing interests in this manuscript.

\section{References}

Abanis, T., Sunday, A., Burani, A., \& Eliabu, B. (2013). Financial management in small and medium enterprises in selected districts in western Uganda. Research journal of finance and accounting, 4(2), Pp. 29-42.

Addo, I. (2017). The effect of financial management practice on the financial performanace of top 100 small and medium enterprises in Kenya :Un published masters thesis in accounting and finance .

Agyei-Mensah, B. K. (2011). Financial management practices of small firms in Ghana: An empirical study. African Journal of Business Management, Vol.5(10), pp. 3781-3793.

Alpkan, L., \& Kaya, S. (2012). Problems and solution proposals for SMes in Turkey:. Emerging market Journal, 2(2), pp 178-196.

Antonakis, J., \&\& Dietz, J. (2011). Looking for validity or testing it? The perils of stepwise regression, extreme-score analysis, heteroscedasticity, and measurement error. Personality and Individual Differences, 50, 409-415. doi:10.1016/j.paid.2010.09.014.

Asandimitra, N., \& Kautsar, A. (2017). Financial Self-Efficacy on Women Entrepreneurs Success.International Journal of Academic Research in Business and Social Sciences, Vol. 7(11) pp 293-300.Available online at https:/ideas.repec.org/a/hur/ijarbs/v7y2017i11p293-300.html.

Ashrafi, R., \& Murtaza, M. (2008). "Use and Impact of ICT on SMEs in Oman.” The Electronic Journal Information Systems Evaluation, Vol. 11(3) pp. 125-138, available online at www.ejise.com.

Asil, H., \& Naralan, A. (2016). Impact of Information Technology on Management in Small and Medium Industries. Journal of Telecommunications System \& Management, 5(3).

Barker, R. (2003). The revolution ahead in financial reporting: Reporting financial performance. Balance Sheet, 11, 19-23.

Berisha-Namani, M. (2009). "The role of information technology in small and medium sized enterprises in Kosova," in Fulbright Academy Conference. pp. 1-8.

Bharadwa, A. (2000). "A resource-based perspective on information technology capability and firm performance: an empirical investigation," MIS quarterly. pp. 169-196.

Boone, H., \& Boone, D. (2012). Analyzing Likert Data. Journal of Extension, 50(2), Retrieved from http:/www.joe.org/joe/2012april/tt2p.shtml.

Buhimila, J., \& Dong, H. (2018). Use of Technology and Financial Literacy on SMEs Practices and Performance in Developing Economies. International Journal of Advanced Computer Science and Applications, Vol. 9 (6), pp. 74-82. 
Chung, S., \& Chuang, J. (2010). The effect of financial management practices on profitability of small and medium enterprises in Veitnam, Meiho: Meiho University.

Cohen, T. (2012). Small Business Is Where the Jobs Will Be Created. Business Day Live. Retrieved from: http://www.bdlive.co.za/opinion/columnists/2012/08/27/Small-business-is-where-the-jobs-will-be-created.

Crawford, I. (1990). Marketing Research Center and network for Agricultural Marketing Training in Eastern and Southern Africa, Harare p 36.

Derbie, M., \& Kassahun, T. (2013). Deterents to Successes of Micro and Small Enterprises in Akaki-Kality Subcity. 5(2), pp 1-33.

Deresse, M., \& Rao, P. (2012). Effect of financial management practices and characteristics on profitability: a study on business enterprises in jimma town, Ethiopia. national monthly refereed journal of research in commerce \& management, 2(5), Pp. 64-75.

Elizabeth, E., Sharon, A., \& Janet, C. (1998). Adoption of Financial Management Practices:A program Assessment. The Journal of Extension, 36(2), retrieved from https:/www.joe.org/index.php.

European Federation of Accountants. (2004). Avoiding Business Failure: A Guide for SMEs, FEE Guide. [online], http://www.fee.be.

Everaert. (2006). Outsourcing of Accounting Tasks in SMEs: An extended TCE Model. Available online at https://www.researchgate.net/publication/24125912.

Fatimah-Salwa, A., Azahari, M., \& Joni-Tamkin, B. (2013). Succsess factors of successful Microcredit Entrepreneurs. Empirical Evidence from Malaysia. International Journal of Businessand Social Science, 4, pp 153-159.

Furnham, A. (1984). Many sides of a coin: The psychology of money usage, Personality and Individual Differences. 5(5), PP. 95-103.

Gebrehiwot, A., \& Wolday, A. (2001). Micro and Small Enterprises (MSE) Development in Ethiopia: Strategy, regulatory changes and remaining constraints:. Ethiopian Journal of Economics, $x(2)$.

Godwin, D. (1994). Antecedent's and consequences of newlywed's cash flow management. Financial counseling and planning, 5 .

Gupta, V. (2008). Comdex 14-In-1 Computer Course Kit,. 2008 Edition ed. New Delhi: Dreamtech Press.

Harif, M., Osman, H., \& Hoe, C. (2010). Financial management practices: an in depth study among CEOs of small and medium enterprises. International Review of Business Research papers, 6(6), pp. 13-35.

Harris, A. (2005). Working capital management: difficult, but rewarding. Financial Executive, 21(4), 52-54.

Hellrigel, D., Slocum, J., \& Woodman, R. (2010). Organizational behaviors.Mason: South Western Cengage Learning

Hira, T., Fanslow, A., \& Vogelsand, R. (1992). Determinants of satisfaction with the preparation for financial emergencies. Financial counseling and planning, 6. 
Ida, \& Dwinta, C. (2010). The effect of locus of control,financial knowledge on financial management behavior. Journal of Business and Economics, 12(3), pp 131-144.

Jacqui, K., \& Macquet, J. (2002). Profiling South Africans township entrepreneurs in order to offer targeted business support. Cape Town: Graduate School of business, University of Cape Town.

Jindrichovska, I. (2013). Financial Management in small and micro enterprises. European Research Studies, $X V I($ Speciallssueon SMEs).

Jodi, L., \& Phyllis, J. (1998). The impact of financial attitudes and knowledge on financial management and satisfaction of recently married individuals. Association for Financial Counselling and Planning. Vol. 9(2).

Joo, S., \& Grable, J. (2004). An Exploratory Framework of the determinants of Financial Satisfaction. Journal of family and economic issues, available online at http://doi.org/10.1023/B:JEEl.0000016722.37994.9F.

Joseph, F. Hair, J., Black, W. C., Babin, B. J., and Anderson, P. E. (2010). Multivariate Data Analysis (7 ${ }^{\text {th }}$ ed.). New Jersey: Pearson Prentice Hall.

Keith, T. (2006). Multiple regression and beyond. PEARSON Allyn \& Bacon.

Lakew, D., \& Rao, D. (2012). Effect of financial management practices and characteristics on profitability: A study on business enterprises in Jimma Town, Ethiopia. National Monthly Refereed Journal of Research in Commerce and Management, 2(5), 2277-1166.

Landzani, W. (2004). Situational analysis of entrepreneurship in South Africa, South Africa. Unpublished master's thesis, University of South Africa, Pretoria.

Lusardi, A., \& Mitchell, O. (2007). Financial Literacy and Retirement Planning: New evidence from the Rand American Life Panel. SSRN Electronic Journal.

McCartney, K., \& Burchinal, M. (2006). Best practices in quantitative methods for developmentalists. Monographs of the Society for Research in Child Development. Financial practice and education, pp. 37-45.

Mcchlery. (2005). Barriers and catalysts to sound financial management systems in small sized enterprises. Journal of Applied Accounting Research vol. 7(3), DOI: 10.1108/96754260580001040.

Messy, A., \& Monticone, C. (2012). (2012). "The status of financial education in Africa".

Nyaga, W. (2016). Factors Affecting Financial Management practice in public secondary schools: a case of schools in Embu west sub-county, Kenya. Unpublished master thesis.

Okpara, J. (2012). Strategic choices, export orientation and export performance of SMEs in Nigeria, Management Decision. Vol. 4(No. 8. Emerald Group Publishing Limited).

Osborne, J., \& Waters, E. (2002). Four assumptions of multiple regression that researchers should always test. Practical Assessment, Research \& Evaluation, 8(2).Retrieved from: http://PAREonline.net/getvn.asp?v=8\&n=2.

Pandey, I. (2012). Financial management. New Delhi,IN: Vikas publishing House PVT Ltd. 
Parrotta, J., \& Johnson, P. (1998). The Impact Of Financial Attitudes And Knowledge On Financial Management And Satisfaction Of Recently Married Individuals, Financial Counseling and Planning. 9(2), PP. 59-75.

Perry, V., \& Morris, M. (2005). Who is control? The role of self perception, knowledge, and income in explaining consumer financial behavior. Journal of consumer affairs, 39(2), pp 299-312.

Prihartono, M., \& Asandimitra, N. (2018). Analysis factors influencing financial management behaviour. International Journal of Academic research in Businessand Social Sciences, 8(8), pp 302-326.

Radam, A., \& Abdullah, M. (2008). "Technical efficiency of small and medium enterprise in Malaysia: A stochastic frontier production model,". International Journal of Economics and Management, vol.2, pp. 395-408.

Rajna, A., Ezat, S., Junid, S. A., \& Moshiri, H. (2011). Financial Management Attitude and Practice among the Medical Practitioners in Public and Private Medical Service in Malaysia. International Journal of Business and Management, 6(8), pp. 105-113.

Rathnasiri, A. (2015). The Financial Management Practices of Small and Medium Enterprises in Sri Lanka. Global Journal of Contemporary Research in Accounting, Auditing and Business Ethics (GJCRA), Vol: 1 Issue: 2, pp 374399.

SBA. (2014). Table of Small Business Size Standards. URL:

sba.gov/sites/default/files/files/Size_Standards_Table.pdf. Last accessed July 14, 2014.

Solomon, T. (2017). Assessmnet of financial management practices: A case study on Small Businesses in Sokoru District ,Ethiopia. Research Journal of Finance and Accounting, 8(19), pp. 8-29.

Thi, N. (2015). Factors Affecting Personal Financial Management Behaviors:Evidence from Vietnam: Proceedings of the Second Asia-Pacific Conference on Global Business, Economics, Finance and Social Sciences (AP15Vietnam Conference). pp.1-6.

Urban, B., \& Naidoo, R. (2012). Business sustainability: Empirical evidence on operational skills in SMEs in South Africa. Journal of Small Business and Enterprise Development, 19, 146-163.

Wambui, E., Kimani, H., \& Muhavani, A. (n.d). Determinants Of Effective Financial Management In Catholic Church Managed Health Institutions In Kenya. African Journal Of Emerging Issues, Vol. 1(9), pp. 48-68.

Yamane, T. (1967). Statistics, An Introductory Analysis, 2nd Ed., New York: Harper and Row.

\section{Figures}




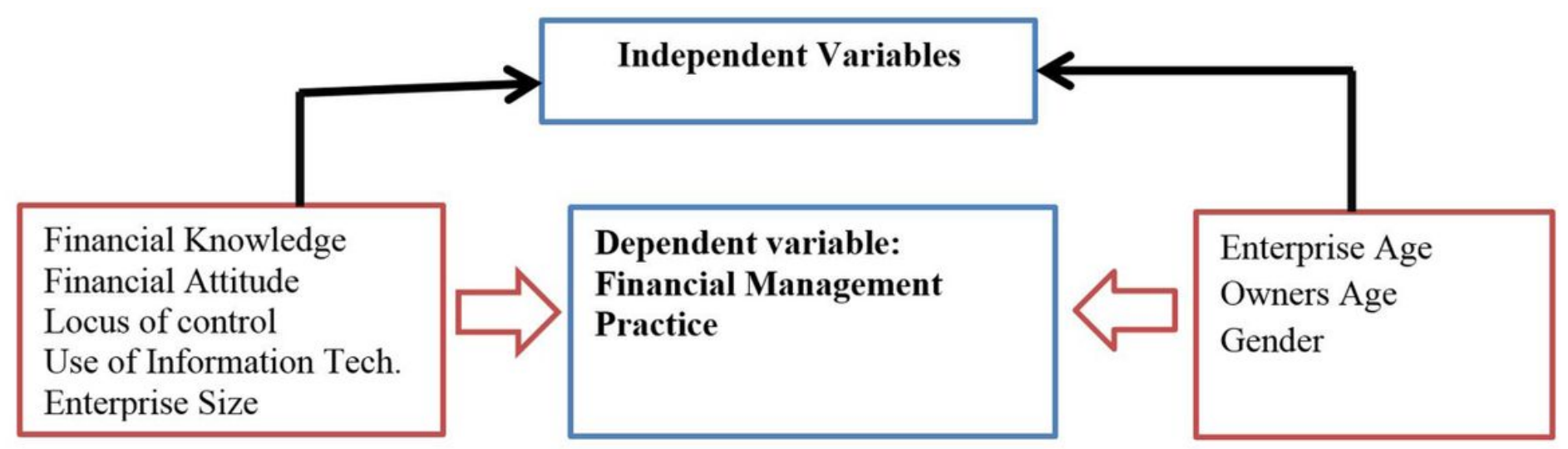

Figure 1

Conceptual Framework of the Study Source: Adopted from literature (Addo, 2017; Marris, 2005 and Rejna et al., 2011).

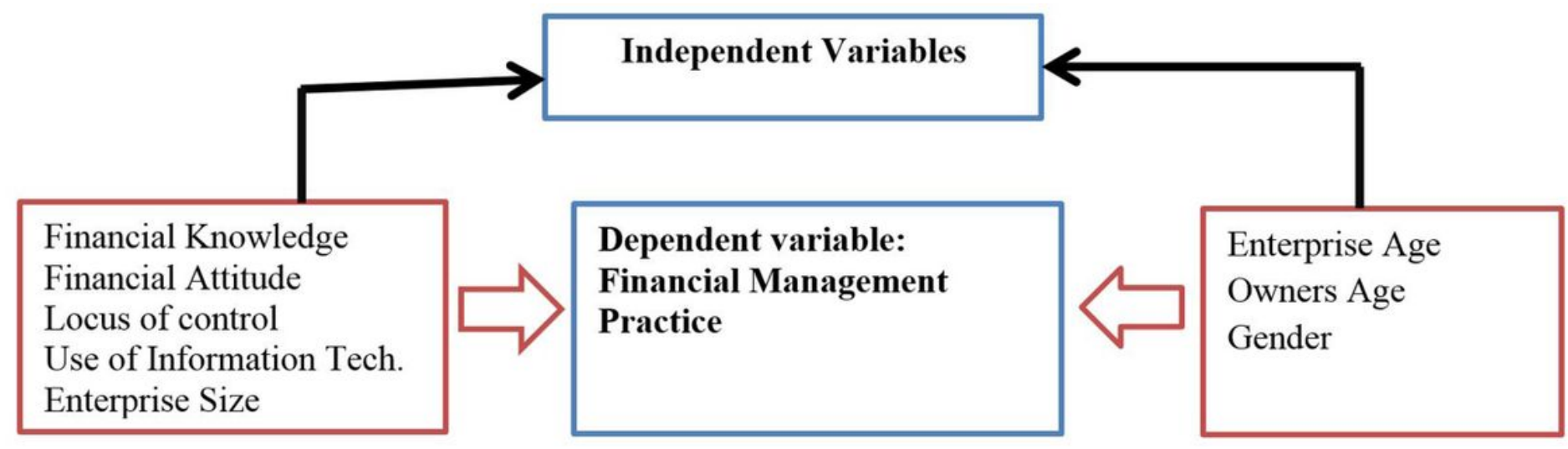

Figure 1

Conceptual Framework of the Study Source: Adopted from literature (Addo, 2017; Marris, 2005 and Rejna et al., 2011).

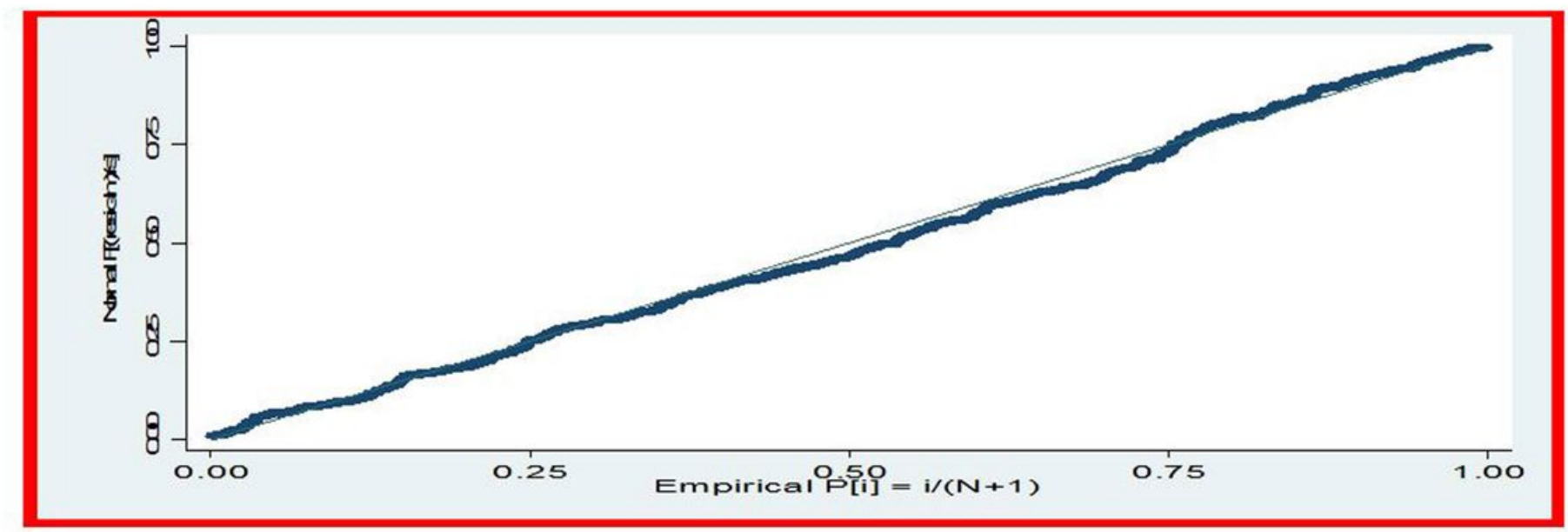

Figure 2

Normality Test using Normal PP-plot Source: STATA output, 2020 


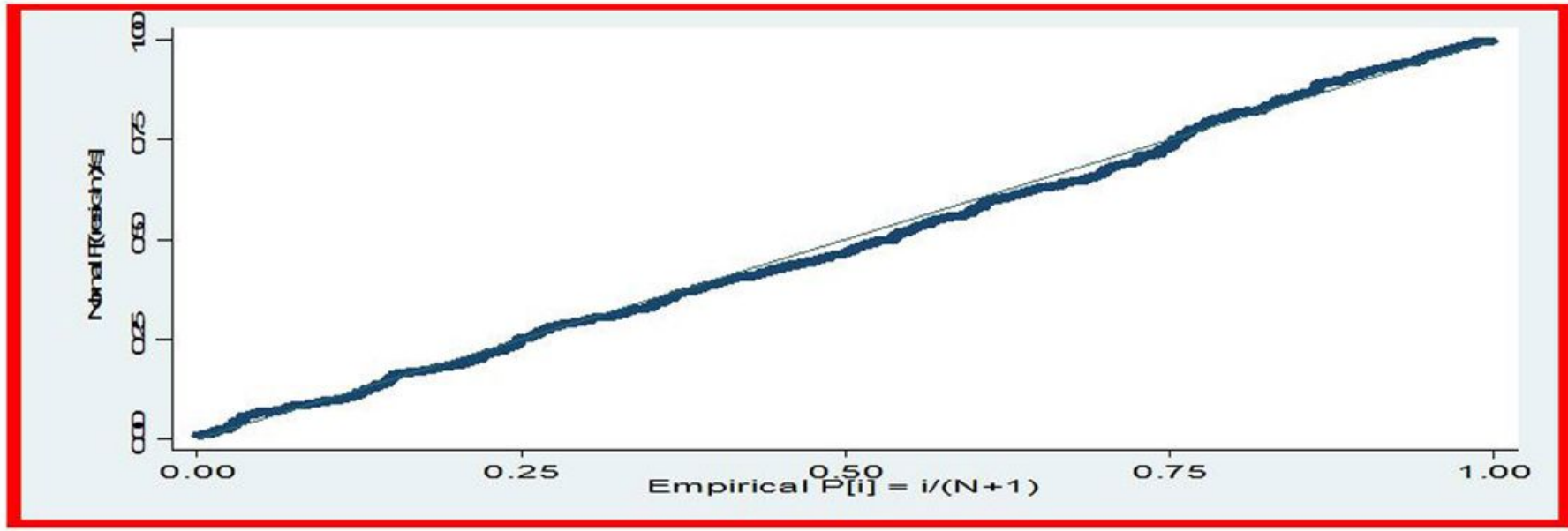

Figure 2

Normality Test using Normal PP-plot Source: STATA output, 2020 